\title{
A concise review of testosterone and bone health
}

\section{Nur-Vaizura Mohamad \\ Ima-Nirwana Soelaiman Kok-Yong Chin}

Department of Pharmacology, Universiti Kebangsaan Malaysia Medical Centre, Kuala Lampur, Malaysia
Correspondence: Kok-Yong Chin Department of Pharmacology, Level 17, Preclinical Building, Universiti Kebangsaan Malaysia Medical Centre, Jalan Yaacob Latif, Bandar Tun Razak, Cheras, 56000 Kuala Lumpur, Malaysia Tel +60 391459573

Email chinkokyong@ppukm.ukm.edu.my
This article was published in the following Dove Press journal:

Clinical Interventions in Aging

22 September 2016

Number of times this article has been viewed

Abstract: Osteoporosis is a condition causing significant morbidity and mortality in the elderly population worldwide. Age-related testosterone deficiency is the most important factor of bone loss in elderly men. Androgen can influence bone health by binding to androgen receptors directly or to estrogen receptors (ERs) indirectly via aromatization to estrogen. This review summarized the direct and indirect effects of androgens on bone derived from in vitro, in vivo, and human studies. Cellular studies showed that androgen stimulated the proliferation of preosteoblasts and differentiation of osteoblasts. The converted estrogen suppressed osteoclast formation and resorption activity by blocking the receptor activator of nuclear factor $\kappa-B$ ligand pathway. In animal studies, activation of androgen and ER $\alpha$, but not ER $\beta$, was shown to be important in acquisition and maintenance of bone mass. Human epidemiological studies demonstrated a significant relationship between estrogen and testosterone in bone mineral density and fracture risk, but the relative significance between the two remained debatable. Human experimental studies showed that estrogen was needed in suppressing bone resorption, but both androgen and estrogen were indispensable for bone formation. As a conclusion, maintaining optimal level of androgen is essential in preventing osteoporosis and its complications in elderly men.

Keywords: androgen, men, osteopenia, osteoporosis, estrogen, skeleton

\section{Introduction}

Osteoporosis is a progressive metabolic bone disease characterized by reduced bone mass and destructive bone microstructural changes, resulting in bone fragility and increased fracture risk. ${ }^{1,2}$ It is a significant global health care issue with an expanding prevalence of nine million patients suffering from osteoporotic fractures, in which 1.6 million are suffering from hip fractures, 1.7 million from lower arm fractures, and 1.4 million from vertebral fractures. ${ }^{3}$ Osteoporotic fracture-associated morbidity and mortality have significant societal impact due to the various medical, social, and financial implications on the patients. ${ }^{4}$

Osteoporosis is a common condition that afflicts both genders, with the lifetime risk of fracture at $\geq 50$ years being $50 \%$ for women and $20 \%$ for men. ${ }^{5-7}$ The major cause of osteoporosis in women is estrogen deficiency due to menopause, while in men, age-related testosterone deficiency. ${ }^{8}$ Despite the higher prevalence in women, men are more prone to be associated with disability and death due to osteoporotic fractures compared to women. ${ }^{9}$ The Dubbo Osteoporosis study demonstrated that death rate 5 years after fracture and second fracture in men aged 60 years (standardized mortality ratio [SMR]: 1.78, 95\% confidence interval [CI]: 0.96-3.31) was higher compared to their women counterpart (SMR: 1.41, 95\% CI: 1.01-1.97). ${ }^{10}$ The incidence of osteoporotic fractures in men increases exponentially later in their life. ${ }^{11}$ This is accompanied by a parallel decrease in their bioavailable testosterone level. ${ }^{12}$ Osteoporosis is also an important side effect of androgen deprivation therapy aimed to treat prostate cancer 
in men. ${ }^{13,14}$ These observations highlight the importance of testosterone in maintaining optimum bone health in men. This review gathered important evidence from cellular, animal, and human studies to present a comprehensive view on the role of testosterone in maintaining bone health, particularly in elderly men.

\section{Androgen and androgen receptor}

"Androgen" is a broad term encompassing testosterone and its precursors which are C19 metabolites of cholesterol. The predominant gonadal androgen in men is testosterone, $95 \%$ of which is secreted by the testes. The remaining $5 \%$ is produced by the adrenals by the conversion of dehydroepiandrosterone. ${ }^{15}$ Testosterone is bound by sex hormone-binding globulin (SHBG) and albumin with strong and weak bonding in blood subsequently. ${ }^{16}$ Effects of testosterone on the body are mediated by its local conversion to $5 \alpha$-dihydrotestosterone by peripheral tissues, which has a greater affinity for androgen receptors (ARs). ${ }^{17,18}$

Androgen synthesis is controlled by the pulsatile release of hypothalamic gonadotropin-releasing hormone (GnRH). At the pituitary gland, GnRH stimulates the release of luteinizing hormone (LH) and follicle-stimulating hormone (FSH) into the general circulation. Both FSH and LH are released by the anterior pituitary gland. FSH stimulates Sertoli cells to support spermatogenesis and secrete inhibin B, which negatively regulates FSH secretion. Meanwhile, LH is needed for the Leydig cells in the testes to produce testosterone. Testosterone stimulates sperm production and virilization, in addition to providing feedback to the hypothalamus and pituitary to regulate GnRH secretion via negative feedback mechanism (Figure 1). ${ }^{19}$

Testosterone possesses strong androgenic and anabolic effects that are important for both women and men, despite that men produce significantly more testosterone than women. ${ }^{20}$ For example, bone growth and maintenance are significantly influenced by testosterone. Previous studies showed that testosterone administration increased the width of epiphyseal growth plate of growing rats directly. ${ }^{21,22}$ This effect was independent of growth hormone and insulin-like growth factor-1. ${ }^{21,22}$ The effects of testosterone in maintaining bone mineral density (BMD) in elderly men are well known and have been summarized by previous authors. ${ }^{16,23,24}$ Thus, androgens take part in building the skeleton of young men and help to prevent bone loss in the elderly men. ${ }^{25}$ Furthermore, testosterone is metabolized via the cytochrome P450 aromatase enzyme into $17 \beta$-estradiol. The aromatization process is also important for bone. ${ }^{26}$ Several case reports indicated that men with mutations in the estrogen receptor (ER) or

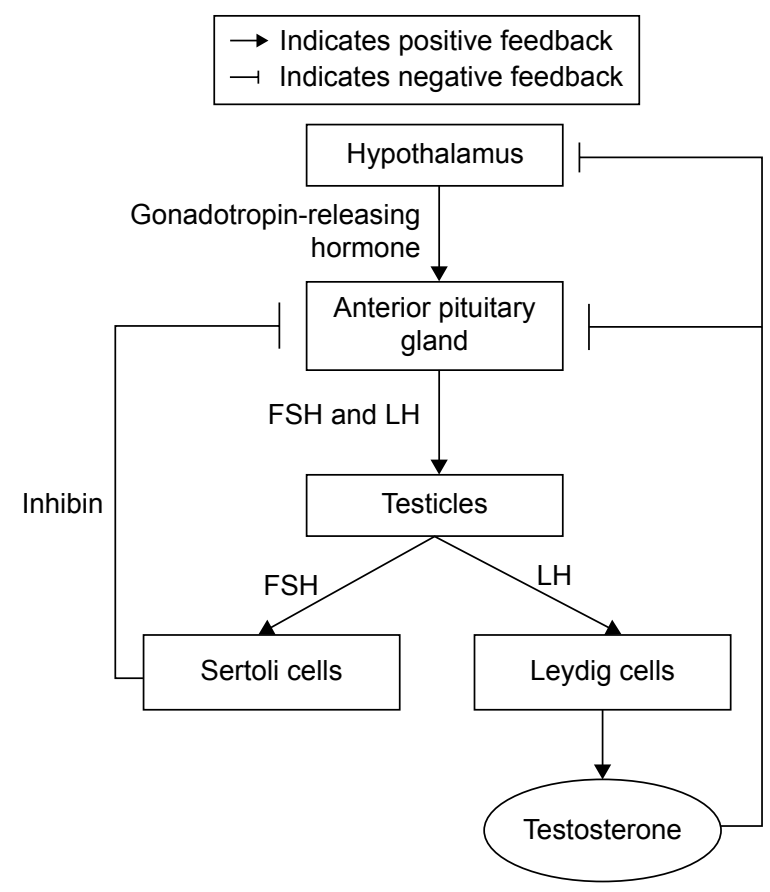

Figure I The synthesis of testosterone.

Abbreviations: FSH, follicle-stimulating hormone; $\mathrm{LH}$, luteinizing hormone.

aromatase genes suffered from severe osteoporosis, ${ }^{27,28}$ suggesting that at least part of the activities of testosterone on the male skeleton are exerted by its aromatization to estradiol. ${ }^{29}$

Sex steroid hormones act on their target cells by binding to members of the nuclear hormone receptor superfamily. Androgens bind to the AR, while estrogens bind to ER $\alpha$ or ER $\beta$. ARs are expressed in bone marrow cell and growth plate. ${ }^{30,31}$ In a study, ARs were expressed in the proliferative and early hypertrophic chondrocytes of sexually mature rats, and only in prehypertrophic chondrocytes in older rats. ${ }^{32}$ Male rats had increased AR expression in the growth plate and metaphyseal bone with higher mRNA- and protein-staining intensities, as well as preferential nuclear staining during sexual maturation, compared to female rats. ${ }^{32}$ This suggests that direct actions of androgens in chondrocytes and in boneforming cells may be involved in establishing the gender differences in the skeleton. However, there is no difference in receptor expression in the growth plate chondrocytes of human males or females. ${ }^{33,34}$ ERs $\alpha$ and $\beta$ are expressed in the human growth plate. This suggested that androgens possibly affect pubertal growth or epiphyseal closure indirectly via aromatization to estrogen. ${ }^{35,36}$

\section{The effects of testosterone on bone cells}

Integrity of our skeletal system is maintained by an intricate process named remodeling which in turn is governed by 
three major types of bone cells: bone-forming osteoblasts, bone-resorbing osteoclasts, and mechanosensor/mediator osteocytes. These bone cells are sensitive to signaling conveyed through hormones, cytokines, minerals, and dietary components. Some of these cells express ARs and ERs, and thus are responsive to both sex hormones. Dysfunction of these cells leads to dysregulation of the remodeling process. In the case of osteoporosis, the rate of bone resorption is greater than bone formation, leading to net bone loss. ${ }^{37,38}$

\section{Osteoblasts}

Osteoblasts are specialized bone-forming cells that have an essential role in bone remodeling, such as production of bone matrix proteins as well as bone mineralization. ${ }^{39}$ Osteoblasts are developed from pluripotent mesenchymal stem cells under the direction of a characterized suite of regulatory transcription factors, such as osterix and runt-related factor $2 .{ }^{40}$ The term "osteoblasts" actually refers to a diverse cellular population that includes immature osteoblast lineage cells as well as differentiating and mature matrix-producing osteoblasts. The mature osteoblasts are responsible for matrix mineralization, while the immature ones regulate formation of osteoclasts. ${ }^{41-43}$

ARs have been identified in cultured human fetal osteoblasts utilizing a nuclear-binding assay. ${ }^{44}$ Subsequent studies identified AR mRNA and protein in osteoblasts. Almost all studies demonstrated that androgen upregulated the expression of ARs in osteoblasts. ${ }^{40,45}$ Stromal cells (precursors of osteoblasts), megakaryocytes, and endothelial cells in the bone marrow express ARs. ${ }^{30,31}$ Studies showed that both testosterone and $5 \alpha$-dihydrotestosterone stimulated proliferation of cultured osteoblast precursors in distinctive species. ${ }^{46,47}$ In addition, androgens have been shown to suppress the apoptosis of osteoblasts. ${ }^{48,49}$ Androgens stimulated interleukin-1 $\beta$ production and enhanced the mitogenic effect of fibroblast growth factor in cultured osteoblasts. ${ }^{50,51}$ Further studies demonstrated that androgens exerted stimulatory, inhibitory, or no effects on the expression of osteoblast markers, such as osteocalcin, collagen type 1 alpha 1, and alkaline phosphatase, and mineralization of extracellular bone matrix. However, the evidence generally suggested that androgens stimulate differentiation of osteoblasts. ${ }^{52-55}$

\section{Osteoclasts}

Osteoclasts originate from the colony-forming unit-granulocyte macrophage hematopoietic cell lineage in the bone marrow. Osteoclast differentiation entails contact with stromal cells of the osteoblastic lineage in bone marrow microenvironment, and stimulation by receptor activator of nuclear factor $\kappa-B$ ligand (RANKL) released by immature osteoblasts, which binds to RANK on osteoclasts. ${ }^{56}$ The effects of RANKL on osteoclasts are tightly regulated by osteoprotegerin (OPG), a decoy receptor of RANKL, also secreted by osteoblast precursors. ${ }^{57}$

The proliferation of osteoclasts after orchidectomy is most likely due to androgen deficiency. Androgens exert their bone-defensive effects indirectly through osteoblastic cells. Orchidectomy will cause the proliferation of osteoblast precursors which secrete RANKL that stimulates osteoclast proliferation and activation, thus resulting in bone loss. ${ }^{58}$ In vitro studies showed that dihydrotestosterone interacted with ARs on osteoclasts and inhibited bone resorption in human, murine, and avian osteoclasts. ${ }^{59}$ In other cell culture studies, androgens were shown to regulate osteoclast formation and survival associated with RANKL pathway, and also to inhibit OPG mRNA levels and protein secretion by osteoblastic cells. ${ }^{38,57,59}$

\section{Osteocytes}

During bone formation, a portion of osteoblasts undergoes terminal separation and entombment by mineralized osteoid, subsequently transforming to osteocytes. ${ }^{60}$ Osteocytes are cased in liquid-filled holes (lacunae) inside the mineralized bone and are found in abundance, representing 90\%-95\% of the total bone cells. ${ }^{61}$ Osteocytes possess long dendritelike processes that cooperate with other osteocytes inside the mineralized bone and interact with osteoblasts on the bone surface. ${ }^{62}$ Osteocytes modulate bone remodeling by responding to mechanical stimuli to prevent accumulation of bone microdamage. ${ }^{63,64}$

In vitro studies suggested that $\mathrm{ER} \alpha$ or $\mathrm{ER} \beta$ translated mechanical forces into prosurvival signals in osteocytes and osteoblasts, independent of estrogens. ${ }^{65}$ Estradiol was shown to prevent osteocytes apoptosis and enhance the production of transforming growth factor-alpha which inhibits osteoclastic bone resorption. ${ }^{66}$ Thus, estrogens converted from testosterone in male could contribute to the anabolic action of osteocytes.

The effects of androgens and estrogens on bone cells are summarized in Figure 2.

\section{The effects of testosterone on animals}

Many animal studies have been performed to further investigate the relative effects of androgen and estrogen on bone. Orchidectomized rodent is a well-characterized animal model for osteoporosis. Following orchidectomy, bone resorption increases at cancellous and endocortical surfaces, 


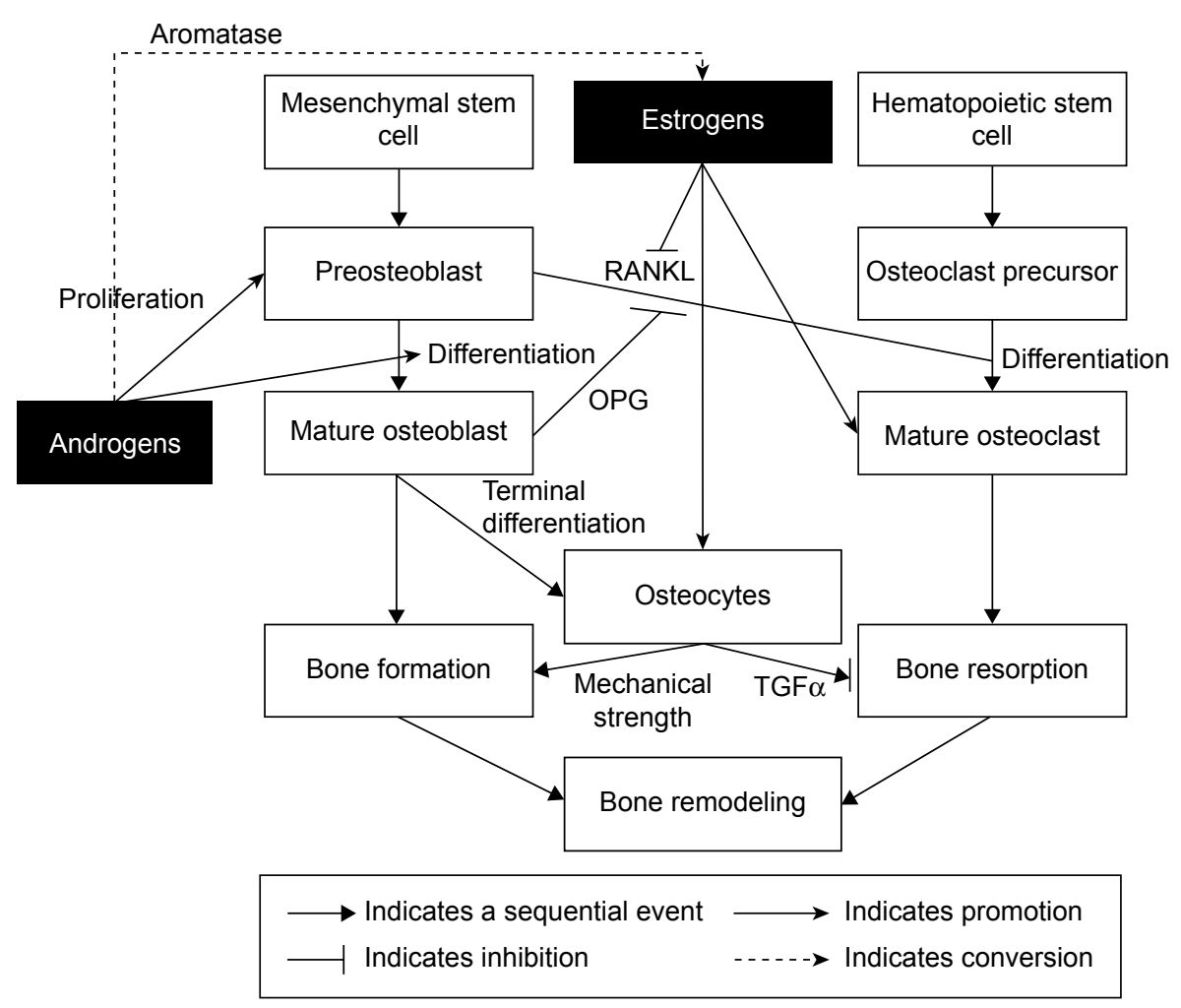

Figure $\mathbf{2}$ The effects of testosterone on bone cells.

Abbreviations: RANKL, receptor activator of nuclear factor $\kappa-B$ ligand; OPG, osteoprotegerin; TGF $\alpha$, transforming growth factor-alpha.

thus reducing cancellous and cortical bone volume. Besides, periosteal bone formation during growth is decreased in orchidectomized rodents. These effects translate to a lower bone strength. ${ }^{67}$

Several studies investigated the bone phenotypic changes induced by androgens, nonaromatizable androgens, and estrogens in orchidectomized rodents. These studies revealed that nonaromatizable androgens stimulated periosteal bone formation and inhibited cancellous bone resorption in orchidectomized rats, although the effect is lesser compared to testosterone and estradiol. ${ }^{68}$ Despites this, it is unclear to what extent the effects of these hormones are pharmacological or physiological, and whether these physiological effects can be extrapolated to the human condition, as estradiol concentration is higher in mice. ${ }^{69}$

Other animal studies on bone phenotype of transgenic male animals with knockout (KO) of AR, ER $\alpha$ or $E R \beta$, or both have been investigated. These studies manipulated the genetic conditions of the mice, in combination with orchidectomy and replacement of androgens and estrogens. The evidence suggests that activation of ER but not AR is involved in longitudinal appendicular skeletal growth in male mice. ${ }^{70}$ Besides, studies in knockout mice again suggest that both $\mathrm{ER} \alpha$ and $\mathrm{AR}$ are involved in enhancing cortical radial bone growth. Both AR and ER $\alpha$ can independently mediate the cancellous bone-sparing effects of sex steroids in male mice, but not ER $\beta .^{71,72}$ These studies have greatly increased the understanding of the role of ERs and ARs in male skeletal growth. The dual mode of action of testosterone is exerted either directly by the AR or indirectly by the ER $\alpha$ through aromatization.

In conclusion, animal evidence suggests that testosterone exerts anabolic effects on different bone surfaces of AR with activation of both $E R \alpha$ and AR on cortical bone and muscle mass; ER $\beta$, on the other hand, seems not to be significantly related to bone growth and maintenance in male mice.

\section{The relationship between testosterone and bone in human studies}

The effects of testosterone on bone health in humans can be measured in terms of BMD and fracture risk. On the other hand, bone formation and resorption markers offer insight on the individual processes that constitute bone remodeling. While association obtained in observational studies is hypothesis generating at best, some experimental studies have been performed to give us direct evidence on the importance of bone health in humans. 
Many prospective studies have demonstrated that the risk of fragility fracture increases progressively as BMD decreases. ${ }^{73}$ The Framingham cohort studies established that femoral and radial BMD decreased significantly with age in both men and women ( $\mathrm{n}=1,154$, aged $68-98$ years). ${ }^{74}$ The decline of BMD is probably due to age-related loss of trabecular and cortical bone. ${ }^{75}$ However, prior to this slow phase of bone loss, degeneration of the cancellous bone is sexually dimorphic, in which rapid-accelerated bone loss after menopause only occurs in women. ${ }^{76}$ In men, cancellous bone loss occurs much later and gradually in life, especially after the age of 70 years. $^{77}$

The associations between circulating testosterone and estrogen, and BMD and fracture in elderly men have been demonstrated in many studies. The US cohort of the Osteoporotic Fractures in Men Study examined the associations between nonvertebral fracture risk and bioavailable testosterone, bioavailable estradiol, and SHBG of elderly men ( $n=5,995$, aged $\geq 65$ years, follow-up duration $=4.7$ years $)$. Each sex hormone was associated with fracture risk, but the combination of low bioavailable testosterone, low bioavailable estradiol, and high SHBG predicted fracture risk the best. ${ }^{78}$ In another cohort study of elderly men in the People's Republic of China ( $n=1,448$, aged $\geq 65$ years, follow-up duration $=4$ years), associations between serum total testosterone, free testosterone, estradiol, bioavailable estradiol, SHBG, BMD, and incident fractures were examined. The results showed that low serum estradiol levels were associated with elevated bone loss and increased risk of fractures. ${ }^{79}$ Similar to the American cohort, the combination of the lowest quartile of free testosterone and bioavailable estradiol and the highest two quartiles of SHBG predicted incident fracture the best. ${ }^{79}$ This suggests that the association between sex hormones and bone health is similar across different populations. The relative importance of androgens and estrogens in maintaining bone health in the elderly remains debatable. Serum testosterone and estrogens were found to be associated significantly with fracture in elderly men $(n=609$, median follow-up duration $=5.8$ years) in the Dubbo Osteoporosis Epidemiology Study. After adjustment for confounding factors, only the relationship between serum testosterone and fracture remained significant. ${ }^{80}$ The Sweden cohort of the Osteoporotic Fractures in Men Study found otherwise, whereby low level of free estradiol, but not free testosterone, was significantly associated with fracture risk in older men $(\mathrm{n}=2,639$, average follow-up duration $=3.3$ years $){ }^{81}$

Interestingly, the relationship between SHBG and bone is dependent on age in men. A study showed that increase in SHBG with age was associated with bone loss in elderly men. ${ }^{78}$ However, in younger men, the relationship between peak bone mass and SHBG was positive rather than negative ${ }^{82-84}$ We postulate that the higher level of SHBG in young men is reflective of higher circulating testosterone level, thus explaining the positive relationship. However, a higher SHBG level is not accompanied by a higher testosterone level in older men because the negative feedback mechanism is dysregulated. Thus, the ensuing decrease in the bioavailability of testosterone causes the deterioration of bone health. Results on testosterone concentrations were less consistent compared to estradiol level in relationship with bone loss or fractures in men, except for very low levels in hypogonadal men, especially those undergoing chemical and surgical castration. They had an increase in bone turnover, bone loss, and fracture risk. ${ }^{85}$

While association obtained in observational studies is hypothesis generating at best, experimental studies in human have been performed to provide direct evidence on the importance of bone health in humans. In an experimental study, young men aged between 20 and 44 years were divided into three groups. The first group received only a $\mathrm{GnRH}$ analog to suppress endogenous sex hormone production, while the second group received a $\mathrm{GnRH}$ analog plus testosterone, and the third group, a GnRH analog plus an aromatase inhibitor, to prevent the conversion of testosterone to estrogen. The results showed that bone resorption markers were increased in the groups receiving $\mathrm{GnRH}$ analog alone and $\mathrm{GnRH}$ analog plus aromatase inhibitor, indicating that estrogen is necessary in suppressing bone resorption. The level of bone formation markers increased greatly in the group receiving $\mathrm{GnRH}$ analog alone than the group receiving GnRH analog and testosterone. Overall, these findings suggest that both estrogens and androgens play independent and fundamental roles in regulating bone resorption in men. ${ }^{86}$

Another study showed that bone resorption markers increased significantly in the absence of both hormones and were unchanged in men when receiving both testosterone and estrogen. Although estrogen prevented the increase in bone resorption markers, testosterone did not exert similar effects. Meanwhile, the bone formation marker, serum osteocalcin, decreased in the absence of both hormones, and its level reverted back to normal with replenishment of either estrogen or testosterone. This study postulated that estrogen may be essential in regulating bone resorption, and both estrogen and testosterone may be critical in maintaining bone formation. ${ }^{87}$

Besides, a study demonstrated that a 12-week administration of aromatase inhibitor in elderly men with hypogonadism 
increased testosterone and reduced estrogen levels but did not affect biochemical markers of bone formation (osteocalcin and amino-terminal propeptide of type 1 collagen), serum OPG, and total body BMD significantly. ${ }^{88}$ However, administration of aromatase inhibitor for 12 months resulted in a decrease in BMD. ${ }^{89}$ Thus, it proved the important role of estrogens and androgens in male bone metabolism (bone biochemical markers) when induced with aromatase inhibitor.

\section{Conclusion}

The current evidence suggests that circulating androgens and estrogens are protective of bone. However, the relative importance between androgens and their derived estrogens in bone is still debatable. Experimental data suggest that androgens influence bone directly via interactions with ARs, and indirectly via binding to ER $\alpha$ and ER $\beta$ after aromatization in adipose or different tissues. Androgens, directly or indirectly through estrogens, preserve trabecular bone principally by diminishing osteoclastogenesis, and both hormones counteract osteoblast apoptosis and stimulate osteoclast apoptosis.

\section{Acknowledgments}

The authors would like to thank Universiti Kebangsaan Malaysia for funding the study via GGPM-2015-036 and FF-2016-008.

\section{Disclosure}

The authors report no conflicts of interest in this work.

\section{References}

1. Delmas PD. Treatment of postmenopausal osteoporosis. Lancet. 2002;359(9322):2018-2026.

2. Tranquilli Leali P, Muresu F, Melis A, Ruggiu A, Zachos A, Carlo Doria C. Skeletal fragility definition. Clin Cases Miner Bone Metab. 2011; $8(2): 11-13$.

3. Johnell O, Kanis J. An estimate of the worldwide prevalence and disability associated with osteoporotic fractures. Osteoporos Int. 2006; 17(12):1726-1733.

4. Oka H, Yoshimura N, Kinoshita H, Saiga A, Kawaguchi H, Nakamura K. Decreased activities of daily living and associations with bone loss among aged residents in a rural Japanese community: the Miyama Study. J Bone Miner Metab. 2006;24(4):307-313.

5. Melton LJ, Atkinson EJ, O'Connor MK, O'Fallon WM, Riggs BL. Bone density and fracture risk in men. J Bone Miner Res. 1998;13(12): 1915-1923.

6. Melton JL. Perspectives: how many women have osteoporosis now? J Bone Miner Res. 1995;10(2):175-177.

7. Kanis J, Johnell O, Oden A, et al. Long-term risk of osteoporotic fracture in Malmö. Osteoporos Int. 2000;11(8):669-674.

8. Riggs BL, Khosla S, Melton LJ 3rd. Sex steroids and the construction and conservation of the adult skeleton. Endocr Rev. 2002;23(3):279-302.

9. Center JR, Nguyen TV, Schneider D, Sambrook PN, Eisman JA. Mortality after all major types of osteoporotic fracture in men and women: an observational study. Lancet. 1999;353(9156):878-882.
10. Bliuc D, Nguyen ND, Milch VE, Nguyen TV, Eisman JA, Center JR. Mortality risk associated with low-trauma osteoporotic fracture and subsequent fracture in men and women. JAMA. 2009;301(5):513-521.

11. Lee J-K, Khir ASM. The incidence of hip fracture in Malaysians above 50 years of age: variation in different ethnic groups. APLAR J Rheum. 2007;10(4):300-305.

12. Chin K-Y, Soelaiman I-N, Mohamed IN, et al. Sex hormones in Malay and Chinese men in Malaysia: are there age and race differences? Clinics (Sao Paulo). 2013;68(2):159-166.

13. Ross RW, Small EJ. Osteoporosis in men treated with androgen deprivation therapy for prostate cancer. J Urol. 2002;167(5):1952-1956.

14. Diamond TH, Higano CS, Smith MR, Guise TA, Singer FR. Osteoporosis in men with prostate carcinoma receiving androgen-deprivation therapy: recommendations for diagnosis and therapies. Cancer. 2004; 100(5):892-899.

15. Vanderschueren D, Laurent MR, Claessens F, et al. Sex steroid actions in male bone. Endocr Rev. 2014;35(6):906-960.

16. Chin KY, Ima-Nirwana S. Sex steroids and bone health status in men. Int J Endocrinol. 2012;2012:208719.

17. Kaufman JM, Vermeulen A. The decline of androgen levels in elderly men and its clinical and therapeutic implications. Endocr Rev. 2005;26(6): 833-876.

18. Labrie F, Cusan L, Gomez JL, et al. Comparable amounts of sex steroids are made outside the gonads in men and women: strong lesson for hormone therapy of prostate and breast cancer. J Steroid Biochem Mol Biol. 2009;113(1):52-56.

19. Fraietta R, Zylberstejn DS, Esteves SC. Hypogonadotropic hypogonadism revisited. Clinics (Sao Paulo). 2013;68 Suppl 1:81-88.

20. Torjesen PA, Sandnes L. Serum testosterone in women as measured by an automated immunoassay and a RIA. Clin Chem. 2004;50(3): 678-679.

21. Phillip M, Maor G, Assa S, Silbergeld A, Segev Y. Testosterone stimulates growth of tibial epiphyseal growth plate and insulin-like growth factor-1 receptor abundance in hypophysectomized and castrated rats. Endocrine. 2001;16(1):1-6.

22. Ren SG, Malozowski S, Sanchez P, Sweet DE, Loriaux DL, Cassorla F. Direct administration of testosterone increases rat tibial epiphyseal growth plate width. Acta Endocrinol. 1989;121(3):401-405.

23. Finkelstein JS, Neer RM, Biller BM, Crawford JD, Klibanski A. Osteopenia in men with a history of delayed puberty. $N$ Engl J Med. 1992;326(9):600-604.

24. Anderson F, Francis R, Selby P, Cooper C. Sex hormones and osteoporosis in men. Calcif Tissue Int. 1998;62(3):185-188.

25. Albright F, Reifenstein EC. Metabolic bone disease: osteoporosis. In: Albright F, Reifenstein EC, editors. The parathyroid glands and metabolic bone disease. Baltimore: Williams and Wilkins; 1948:145-204.

26. Gennari L, Nuti R, Bilezikian JP. Aromatase activity and bone homeostasis in men. J Clin Endocrinol Metab. 2004;89(12):5898-5907.

27. Khosla S, Melton III LJ, Riggs BL. Estrogen and the male skeleton. J Clin Endocrinol Metab. 2002;87(4):1443-1450.

28. Smith R. Corticosteroids and osteoporosis. Thorax. 1990;45(8):573-578.

29. Carani C, Qin K, Simoni M, et al. Effect of testosterone and estradiol in a man with aromatase deficiency. N Engl J Med. 1997;337(2):91-95.

30. Braidman IP, Hainey L, Batra G, Selby PL, Saunders PT, Hoyland JA. Localization of estrogen receptor $\beta$ protein expression in adult human bone. J Bone Miner Res. 2001;16(2):214-220.

31. Gruber R, Czerwenka K, Wolf F, Ho G-M, Willheim M, Peterlik M. Expression of the vitamin $\mathrm{D}$ receptor, of estrogen and thyroid hormone receptor $\alpha$-and $\beta$-isoforms, and of the androgen receptor in cultures of native mouse bone marrow and of stromal/osteoblastic cells. Bone. 1999;24(5):465-473.

32. van der Eerden B, van Til N, Brinkmann A, Lowik C, Wit J, Karperien M. Gender differences in expression of androgen receptor in tibial growth plate and metaphyseal bone of the rat. Bone. 2002;30(6):891-896.

33. Carrascosa A, Audi L, Ferrandez M, Ballabriga A. Biological effects of androgens and identification of specific dihydrotestosterone-binding sites in cultured human fetal epiphyseal chondrocytes. J Clin Endocrinol Metab. 1990;70(1):134-140. 
34. Ben-Hur H, Thole H, Mashiah A, et al. Estrogen, progesterone and testosterone receptors in human fetal cartilaginous tissue: immunohistochemical studies. Calcif Tissue Int. 1997;60(6):520-526.

35. Bord S, Horner A, Beavan S, Compston J. Estrogen receptors $\alpha$ and $\beta$ are differentially expressed in developing human bone 1. J Clin Endocrinol Metab. 2001;86(5):2309-2314.

36. Nilsson LO, Boman A, Sävendahl L, et al. Demonstration of estrogen receptor- $\beta$ immunoreactivity in human growth plate cartilage. J Clin Endocrinol Metab. 1999;84(1):370-373.

37. Feng X, McDonald JM. Disorders of bone remodeling. Annu Rev Pathol. 2011;6:121-145.

38. Hadjidakis DJ, Androulakis II. Bone remodeling. Ann N Y Acad Sci. 2006;1092(1):385-396.

39. Karsenty G. Transcriptional control of skeletogenesis. Annu Rev Genomics Hum Genet. 2008;9:183-196.

40. Raggatt LJ, Partridge NC. Cellular and molecular mechanisms of bone remodeling. J Biol Chem. 2010;285(33):25103-25108.

41. Corral DA, Amling M, Priemel M, et al. Dissociation between bone resorption and bone formation in osteopenic transgenic mice. Proc Natl Acad Sci U S A. 1998;95(23):13835-13840.

42. Gori F, Hofbauer LC, Dunstan CR, Spelsberg TC, Khosla S, Riggs BL. The expression of osteoprotegerin and RANK ligand and the support of osteoclast formation by stromal-osteoblast lineage cells is developmentally regulated 1. Endocrinology. 2000;141(12):4768-4776.

43. Komori T, Yagi H, Nomura S, et al. Targeted disruption of Cbfa1 results in a complete lack of bone formation owing to maturational arrest of osteoblasts. Cell. 1997;89(5):755-764.

44. Colvard DS, Eriksen EF, Keeting PE, et al. Identification of androgen receptors in normal human osteoblast-like cells. Proc Natl Acad Sci US A. 1989;86(3):854-857.

45. Kasperk C, Helmboldt A, Börcsök I, et al. Skeletal site-dependent expression of the androgen receptor in human osteoblastic cell populations. Calcif Tissue Int. 1997;61(6):464- 473.

46. Damien E, Price J, Lanyon L. Mechanical strain stimulates osteoblast proliferation through the estrogen receptor in males as well as females. J Bone Miner Res. 2000;15(11):2169-2177.

47. Nakano Y, Morimoto I, Ishida O, et al. The receptor, metabolism and effects of androgen in osteoblastic MC3T3-E1 cells. Bone Miner. 1994;26(3):245-259.

48. Almeida M, Han L, Ambrogini E, Bartell SM, Manolagas SC. Oxidative stress stimulates apoptosis and activates NF- $\kappa$ B in osteoblastic cells via a PKC $\beta /$ p66shc signaling cascade: counter regulation by estrogens or androgens. Mol Endocrinol. 2010;24(10):2030-2037.

49. Wiren KM, Toombs AR, Semirale AA, Zhang X. Osteoblast and osteocyte apoptosis associated with androgen action in bone: requirement of increased Bax/Bcl-2 ratio. Bone. 2006;38(5):637-651.

50. Keeting PE, Rifas L, Harris SA, et al. Evidence for interleukin-1 $\beta$ production by cultured normal human osteoblast-like cells. $J$ Bone Miner Res. 1991;6(8):827-833.

51. Kasperk C, Fitzsimmons R, Strong D, et al. Studies of the mechanism by which androgens enhance mitogenesis and differentiation in bone cells. J Clin Endocrinol Metab. 1990;71(5):1322-1329.

52. Kasperk CH, Wergedal JE, Farley JR, Linkhart TA, Turner RT, Baylink DJ. Androgens directly stimulate proliferation of bone cells in vitro. Endocrinology. 1989;124(3):1576-1578.

53. Kasperk CH, Wakley GK, Hierl T, Ziegler R. Gonadal and adrenal androgens are potent regulators of human bone cell metabolism in vitro. J Bone Miner Res. 1997;12(3):464-471.

54. Hofbauer LC, Hicok KC, Khosla S. Effects of gonadal and adrenal androgens in a novel androgen-responsive human osteoblastic cell line. $J$ Cell Biochem. 1998;71(1):96-108.

55. Chin K-Y, Soelaiman IN. The effects of orchidectomy and supraphysiological testosterone administration on trabecular bone structure and gene expression in rats. Aging Male. 2015;18(1):60-66.

56. Suda T, Takahashi N, Udagawa N, Jimi E, Gillespie MT, Martin TJ. Modulation of osteoclast differentiation and function by the new members of the tumor necrosis factor receptor and ligand families. Endocr Rev. 1999;20(3):345-357.
57. Hofbauer LC, Hicok KC, Chen D, Khosla S. Regulation of osteoprotegerin production by androgens and anti-androgens in human osteoblastic lineage cells. Eur J Endocrinol. 2002;147(2):269-273.

58. Clarke BL, Khosla S. Androgens and bone. Steroids. 2009;74(3): 296-305.

59. Huber DM, Bendixen AC, Pathrose P, et al. Androgens suppress osteoclast formation induced by RANKL and macrophage-colony stimulating factor. Endocrinology. 2001;142(9):3800-3808.

60. Palumbo C. A three-dimensional ultrastructural study of osteoidosteocytes in the tibia of chick embryos. Cell Tissue Res. 1986;246(1): 125-131.

61. Bonewald LF. Osteocytes as dynamic multifunctional cells. Ann NY Acad Sci. 2007;1116(1):281-290.

62. Kamioka H, Honjo T, Takano-Yamamoto T. A three-dimensional distribution of osteocyte processes revealed by the combination of confocal laser scanning microscopy and differential interference contrast microscopy. Bone. 2001;28(2):145-149.

63. Verborgt O, Tatton NA, Majeska RJ, Schaffler MB. Spatial distribution of Bax and Bcl-2 in osteocytes after bone fatigue: complementary roles in bone remodeling regulation? J Bone Miner Res. 2002; 17(5):907-914.

64. Verborgt O, Gibson GJ, Schaffler MB. Loss of osteocyte integrity in association with microdamage and bone remodeling after fatigue in vivo. J Bone Miner Res. 2000;15(1):60-67.

65. Aguirre JI, Plotkin LI, Gortazar AR, et al. A novel ligand-independent function of the estrogen receptor is essential for osteocyte and osteoblast mechanotransduction. J Biol Chem. 2007;282(35):25501-25508.

66. Tomkinson A, Reeve J, Shaw R, Noble B. The death of osteocytes via apoptosis accompanies estrogen withdrawal in human bone 1. J Clin Endocrinol Metab. 1997;82(9):3128-3135.

67. Vanderschueren D, Vandenput L, Boonen S, Lindberg MK, Bouillon R, Ohlsson C. Androgens and bone. Endocr Rev. 2004;25(3):389-425.

68. Vandenput L, Boonen S, Van Herck E, Swinnen J, Bouillon R, Vanderschueren D. Evidence from the aged orchidectomized male rat model that $17 \beta$-estradiol is a more effective bone-sparing and anabolic agent than 5 $\alpha$-dihydrotestosterone. J Bone Miner Res. 2002;17(11): 2080-2086.

69. Modder U, Riggs BL, Spelsberg TC, et al. Dose-response of estrogen on bone versus the uterus in ovariectomized mice. Eur J Endocrinol. 2004;151(4):503-510.

70. Vidal O, Lindberg MK, Hollberg K, et al. Estrogen receptor specificity in the regulation of skeletal growth and maturation in male mice. Proc Natl Acad Sci U S A. 2000;97(10):5474-5479.

71. Lindberg MK, Movérare S, Skrtic S, et al. Two different pathways for the maintenance of trabecular bone in adult male mice. J Bone Miner Res. 2002;17(4):555-562.

72. Ke H, Brown T, Qi H, et al. The role of estrogen receptor-b in the early age-related bone gain and later age-related bone loss in female mice. J Musculoskelet Neuronal Interact. 2002;2(5):479-488.

73. Kaufman J, Johnell O, Abadie E, et al. Background for studies on the treatment of male osteoporosis: state of the art. Ann Rheum Dis. 2000;59(10):765-772.

74. Hannan MT, Felson DT, Anderson JJ. Bone mineral density in elderly men and women: results from the Framingham osteoporosis study. J Bone Miner Res. 1992;7(5):547-553.

75. Riggs BL, Khosla S, Melton LJ. A unitary model for involutional osteoporosis: estrogen deficiency causes both type I and type II osteoporosis in postmenopausal women and contributes to bone loss in aging men. J Bone Miner Res. 1998;13(5):763-773.

76. Burger $\mathrm{H}$, de Laet $\mathrm{C}$, van Daele $\mathrm{P}$, et al. Risk factors for increased bone loss in an elderly population the rotterdam study. Am J Epidemiol. 1998;147(9):871-879.

77. Cawthon PM, Ewing SK, McCulloch CE, et al. Loss of hip BMD in older men: the osteoporotic fractures in men (MrOS) study. $J$ Bone Miner Res. 2009;24(10):1728-1735.

78. LeBlanc ES, Nielson CM, Marshall LM, et al. The effects of serum testosterone, estradiol, and sex hormone binding globulin levels on fracture risk in older men. J Clin Endocrinol Metab. 2009;94(9):3337-3346. 
79. Woo J, Kwok T, Leung JC, Ohlsson C, Vandenput L, Leung PC. Sex steroids and bone health in older Chinese men. Osteoporos Int. 2012; 23(5):1553-1562.

80. Meier C, Nguyen TV, Handelsman DJ, et al. Endogenous sex hormones and incident fracture risk in older men: the Dubbo Osteoporosis Epidemiology Study. Arch Intern Med. 2008;168(1):47-54.

81. Mellstrom D, Vandenput L, Mallmin H, et al. Older men with low serum estradiol and high serum SHBG have an increased risk of fractures. J Bone Miner Res. 2008;23(10):1552-1560.

82. Lorentzon M, Swanson C, Andersson N, Mellström D, Ohlsson C. Free testosterone is a positive, whereas free estradiol is a negative, predictor of cortical bone size in young Swedish men: the GOOD study. J Bone Miner Res. 2005;20(8):1334-1341.

83. Vanbillemont G, Lapauw B, Bogaert V, et al. Sex hormone-binding globulin as an independent determinant of cortical bone status in men at the age of peak bone mass. J Clin Endocrinol Metab. 2010;95(4): 1579-1586.

84. Khosla S, Amin S, Singh RJ, Atkinson EJ, Melton LJ 3rd, Riggs BL. Comparison of sex steroid measurements in men by immunoassay versus mass spectroscopy and relationships with cortical and trabecular volumetric bone mineral density. Osteoporos Int. 2008;19(10): 1465-1471.
85. Daniell HW, Dunn SR, Ferguson DW, Lomas G, Niazi Z, Stratte PT. Progressive osteoporosis during androgen deprivation therapy for prostate cancer. J Urol. 2000;163(1):181-186.

86. Leder BZ, LeBlanc KM, Schoenfeld DA, Eastell R, Finkelstein JS. Differential effects of androgens and estrogens on bone turnover in normal men. J Clin Endocrinol Metab. 2003;88(1):204-210.

87. Falahati-Nini A, Riggs BL, Atkinson EJ, O'Fallon WM, Eastell R, Khosla S. Relative contributions of testosterone and estrogen in regulating bone resorption and formation in normal elderly men. J Clin Invest. 2000;106(12):1553-1560.

88. Leder BZ, Finkelstein JS. Effect of aromatase inhibition on bone metabolism in elderly hypogonadal men. Osteoporos Int. 2005;16(12): 1487-1494.

89. Burnett-Bowie S-AM, McKay EA, Lee H, Leder BZ. Effects of aromatase inhibition on bone mineral density and bone turnover in older men with low testosterone levels. J Clin Endocrinol Metab. 2009;94(12): 4785-4792.
Clinical Interventions in Aging

\section{Publish your work in this journal}

Clinical Interventions in Aging is an international, peer-reviewed journal focusing on evidence-based reports on the value or lack thereof of treatments intended to prevent or delay the onset of maladaptive correlates of aging in human beings. This journal is indexed on PubMed Central, MedLine,

\section{Dovepress}

CAS, Scopus and the Elsevier Bibliographic databases. The manuscript management system is completely online and includes a very quick and fair peer-review system, which is all easy to use. Visit http://www.dovepress. com/testimonials.php to read real quotes from published authors. 